Proceedings of the 10th International Ruminant Reproduction Symposium (IRRS 2018); Foz do Iguaçu, PR, Brazil, September 16th to 20th, 2018.

\title{
Programs for fixed-time artificial insemination in South American beef cattle
}

\author{
Gabriel A. Bó ${ }^{1,2, *}$, Emilio Huguenine ${ }^{1,4}$, José Javier de la Mata ${ }^{1,5}$, Richard Núñez-Olivera ${ }^{6}$, \\ Pietro S. Baruselli ${ }^{3}$, Alejo Menchaca ${ }^{6}$ \\ ${ }^{1}$ Instituto A.P. de Ciencias Básicas y Aplicadas, Carrera de Medicina Veterinaria, Universidad Nacional de Villa María, Córdoba, \\ Argentina. \\ ${ }^{2}$ Instituto de Reproducción Animal Córdoba (IRAC), Zona Rural General Paz, 5145, Córdoba, Argentina. \\ ${ }^{3}$ Departamento de Reprodução Animal, FMVZ-USP, CEP 05508-000 São Paulo, Brazil. \\ ${ }^{4}$ Private Practice, SAV, San Luis, Argentina. \\ ${ }^{5}$ Facultad de Agronomía, Universidad Nacional de La Pampa, Santa Rosa, La Pampa, Argentina. \\ ${ }^{6}$ Fundación IRAUy, Instituto de Reproducción Animal Uruguay, Montevideo, Uruguay.
}

\begin{abstract}
Fixed-time artificial insemination (FTAI) has been widely applied in South America within the last 20 years for the genetic improvement of commercial beef herds. Most FTAI treatments for beef cattle used in South America are based on the use of progesterone (P4) releasing devices and estradiol to synchronize follicle wave emergence, with pregnancies per $\mathrm{AI}(\mathrm{P} / \mathrm{AI})$ ranging from 40 to $60 \%$. More recent protocols focusing on extending the interval from device removal to FTAI (i.e. increasing the growing period of the ovulatory follicle) have been reported to improve $\mathrm{P} / \mathrm{AI}$ in beef cattle. These new protocols and the more traditional FTAI protocols have also been adapted for use with sexed-sorted semen with acceptable P/AI in beef cattle. Finally, color-flow Doppler ultrasonography has been incorporated recently to determine the vascularity of the CL and thereby detect pregnancy as early as Day 22 after the first AI for resynchronization of ovulation for a second FTAI in nonpregnant animals. In summary, FTAI protocols have facilitated the widespread application of AI in South American beef cattle by allowing for the insemination and re-insemination of herds during a defined breeding season, without the necessity of clean up bulls to achieve high pregnancy rates.
\end{abstract}

Keywords: color-flow Doppler ultrasonography, proestrus length, sexed-sorted semen.

\section{Introduction}

Artificial insemination (AI) is the most useful method for genetic improvement in cattle, and because estrus detection is difficult and inefficient, fixed-time artificial insemination (FTAI) is necessary. There are basically two types of FTAI protocols currently used in beef cattle; GnRH-based and estradiol-based protocols, both of which are combined with progesterone (P4) releasing devices and prostaglandin $\mathrm{F}_{2 \alpha}\left(\mathrm{PGF}_{2 \alpha}\right)$. Estradiol/P4-based protocols are most commonly used in South-American beef herds because of the availability of estradiol, its high effectiveness both in heifers and in cows in postpartum anestrus, and its relative low cost. With 20 years of experience with FTAI in South America, results are now more consistent with pregnancy per $\mathrm{AI}(\mathrm{P} / \mathrm{AI})$ ranging between 40 to 60\% (Bó et al., 2013). However, recently developed protocols that extend the period from P4 device removal to ovulation (defined as the proestrus period) have provided new opportunities for increasing $\mathrm{P} / \mathrm{AI}$ (Bridges et al., 2008; Bó et al., 2016). Furthermore, treatments to re-synchronize ovulation have provided the opportunity to do sequential FTAI, without the necessity of using clean-up bulls (Baruselli et al., 2017a). The objective of this manuscript is to review protocols that are currently available and discuss their applications in beef herds

\section{Estradiol/P4-based treatments for FTAI}

Estradiol and P4 treatments consist of insertion of a $\mathrm{P} 4$ releasing device and the administration of $2 \mathrm{mg}$ of estradiol benzoate (EB) on random days of the cycle (Day 0 ; to induce follicle atresia and synchronize follicular wave emergence), $\mathrm{PGF}_{2 \alpha}$ at the time of $\mathrm{P} 4$ device removal on Days 7, 8 or 9 (to ensure luteolysis) and the subsequent application of $1 \mathrm{mg}$ EB $24 \mathrm{~h}$ later, GnRH or LH $54 \mathrm{~h}$ later or 0.5 or $1 \mathrm{mg}$ of estradiol cypionate (ECP) at the time of P4 device removal (Bó et al., 2013) to synchronize ovulation. Most practitioners prefer the use of ECP to synchronize ovulation because it reduces the need to handle animals for the administration of EB. Treatment protocols that are applied to suckling beef cows usually include the administration of equine chorionic gonadotropin (eCG) at the time of removal the P4 device (Baruselli et al., 2004; Bó et al., 2013), which has been reported to stimulate the growth of the dominant follicle, increased ovulation rate (Sá Filho et al., 2010a; Núñez-Olivera et al., 2014) and circulating P4 concentrations in the subsequent luteal phase in cows experiencing postpartum anestrus (Baruselli et al., 2012; Núñez-Olivera et al., 2014). Although the use of eCG has been widely used in Bos indicus herds with high incidence of postpartum anestrus (Baruselli et al., 2004; Sá Filho et al., 2010a) improvements in Bos taurus herds with high incidence of postpartum anestrus have been also reported (Menchaca et al., 2013; Núñez-Olivera et al., 2014), while no improvements in $\mathrm{P} / \mathrm{AI}$ has been reported in herds in with high proportions of cycling cows or heifers at the time of treatment (reviewed in Bó and Baruselli, 2014). 


\section{GnRH-based treatments}

GnRH-based protocols are used widely for beef cattle in North-America and Europe, but GnRH use is limited in South-America because of cost and the availability of estradiol esters. The most commonly used protocol is called Co-Synch; GnRH is administered at the time of FTAI to synchronize ovulation (Geary et al., 2001). In general Co-Synch protocols have included the insertion of a P4 device to overcome poor ovulation rates after the first $\mathrm{GnRH}$ in heifers (Martinez et al., 2002) and in postpartum suckled beef cows experiencing anestrus (Lamb et al., 2001). Data on the addition of eCG to GnRH/P4-based treatment protocols have been more controversial, with reported improvements in P/AI in Bos indicus (Pincinato et al., 2012) and Bos taurus cows in postpartum anestrus (Huguenine et al., 2013) and in primiparous Bos taurus cows that had not been pre-synchronized (Small et al., 2009). However, no improvement in P/AI has been reported in Bos taurus cows with low incidence of postpartum anestrus and moderate to high body condition scores (BCS; Marquezini et al., 2013).

\section{Protocols that prolong the proestrus period}

\author{
Extending the proestrus period in GnRH/P4-based \\ protocols
}

New protocols for FTAI were developed to prolong the period from $\mathrm{P} 4$ device removal to ovulation with the objective of incrementing the period of preovulatory estradiol exposure and improving uterine function and early embryo development (Bridges et al., $2008 ; 2012)$. The protocol was named 5-day CoSynch $+\mathrm{P} 4$ and resulted in higher P/AI than with the 7day Co-Synch+P4 in beef cows (Bridges et al., 2008; Whittier et al., 2013). The main changes in this protocol was a reduced period of insertion of the $\mathrm{P} 4$ releasing device from 7 to 5 days, to avoid the adverse effects of persistent follicles on fertility of the cows not ovulating to the first GnRH, and to prolong the period from $\mathrm{P} 4$ device removal to the $\mathrm{GnRH}$ treatment to increase the exposure to circulating estradiol concentrations prior to ovulation (Bridges et al., 2014). Higher estradiol concentrations in the preovulatory period have been associated to an increased ability of the uterus to support conceptus development (Bridges et al., 2013, Binelli et al., 2014) and were also related to lower embryonic losses in the time period between maternal recognition of pregnancy and placental attachment (Madsen et al., 2015).

Because of the shorter interval between the first GnRH and induction of luteolysis in the 5-day CoSynch $+\mathrm{P} 4$ protocol, a single administration of $\mathrm{PGF}_{2 \alpha}$ was not effective in inducing luteolysis in beef cows that had ovulated to the GnRH (Souto et al., 2009); two doses of $\mathrm{PGF}_{2 \alpha} 8$ to 12 hours apart resulted in higher P/AI (Kasimamickam et al., 2009). In a large field trial with 2,465 postpartum beef cows, P/AI was greater $(\mathrm{P}<0.05)$ in cows receiving $2 \mathrm{PGF}_{2 \alpha} 8 \mathrm{~h}$ apart $(55 \%)$ than those receiving only one $\mathrm{PGF}_{2 \alpha}(48 \%)$, with those receiving $2 \mathrm{PGF}_{2 \alpha}$ at the same time being intermediate (51\%; Bridges et al., 2012). Hence, double $\mathrm{PGF}_{2 \alpha}$ given 8 to $24 \mathrm{~h}$ apart seemed necessary to maximize fertility with the 5-day protocol. If farm conditions do not permit the extra handling, a double dose of $\mathrm{PGF}_{2 \alpha}$ given at device removal would be an acceptable alternative.

The 5-day Co-Synch+P4 protocol has also been investigated in Bos indicus cows in South America, with lower P/AI in suckled Nelore cows than those treated with the conventional 8-day estradiol/P4-based protocol (Ferraz Jr et al., 2016). An important difference was that $400 \mathrm{IU}$ eCG was used in the estradiol/P4-based protocol but it was not used in the 5-day $\mathrm{Co}-\mathrm{Synch}+\mathrm{P} 4$ protocol. To confirm this notion, we have reported no differences in $\mathrm{P} / \mathrm{AI}$ in cycling cows treated with the 5-day CoSynch $+\mathrm{P} 4$ and the estradiol/P4-based protocol, but P/AI was higher in cows in postpartum anestrus that received $400 \mathrm{IU}$ eCG at P4 device removal (5-day Co-Synch+P4: 46.3\%, 120/259; estradiol/P4-based: 54.5\%, 151/277) than in cows treated with 5-day Co-Synch $+\mathrm{P} 4$ but without eCG $(26.8 \%, 71 / 265 ; \mathrm{P}<0.05$; Huguenine et al., 2013).

The 5-day Co-Synch+P4 protocol has also been tested in heifers (Day, 2015), with some modifications introduced; for example, Colazo and Ambrose (2011) and Cruppe et al. (2014) showed that P/AI did not differ in heifers that did not receive GnRH at the time of insertion of a $\mathrm{P} 4$ device. The important issue with not administering the first $\mathrm{GnRH}$ is that a single injection of $\mathrm{PGF}_{2 \alpha}$ is all that is required. The two alternative 5-day Co-Synch+P4 protocols are depicted in Fig. 1.

Controversy still exists concerning the necessity of using one or two doses of $\mathrm{PGF}_{2 \alpha}$, when the first GnRH is administered with no reported differences (Kasimanickam et al., 2014) and higher P/AI when two doses of $\mathrm{PGF}_{2 \alpha}$ were used with intervals between 6 to $24 \mathrm{~h}$ (Day, 2015; Peterson et al., 2011). In relation to the optimal timing of FTAI, Kasimanickam et al. (2012) reported higher P/AI with heifers inseminated at $56 \mathrm{~h}$ after device removal than those inseminated at $72 \mathrm{~h}$ and Day (2015) suggested FTAI 60 to $66 \mathrm{~h}$ after P4 device removal or insemination $12 \mathrm{~h}$ after estrus using tail-patches or tail-paint and FTAI/GnRH to all those not in heat by $72 \mathrm{~h}$. Certainly, expression of estrus has been shown to influence P/AI in cows (Richarson et al., 2016) and Colazo et al. (2017) have reported similar findings in heifers inseminated with sexed-sorted semen; suggesting the possibility of splitting the insemination based on estrus expression (i.e., delaying the insemination in those animals not showing estrus by the time of FTAI). 
(A)

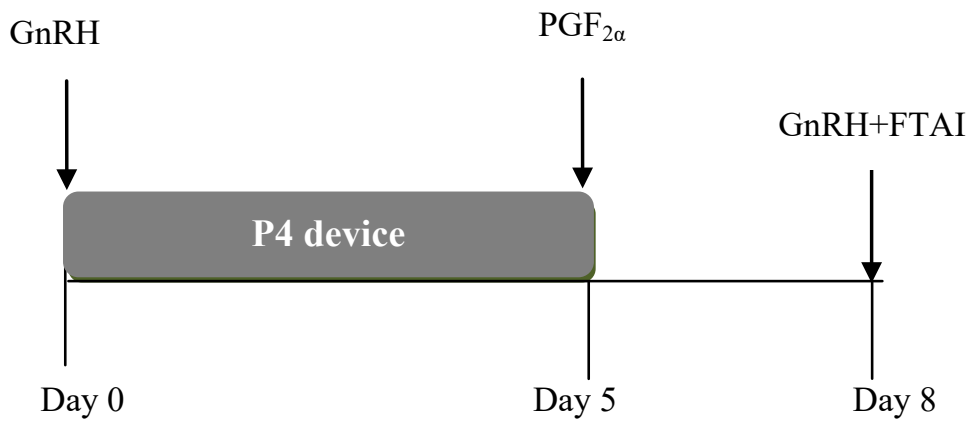

(B)

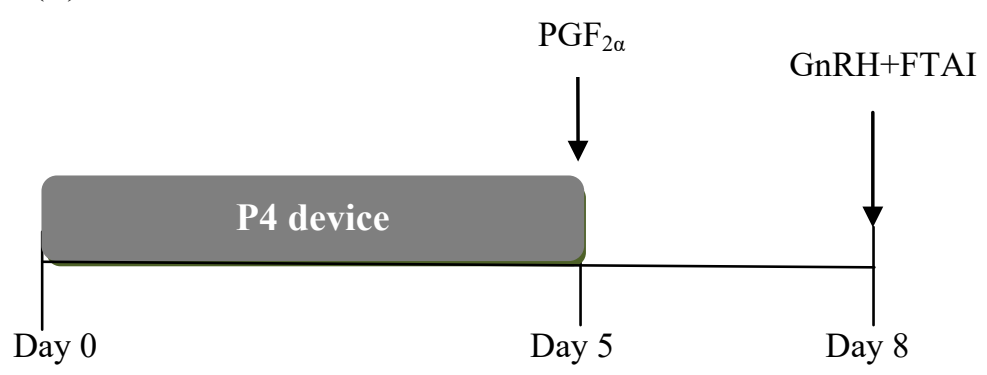

Figure 1. Two protocols for FTAI in beef cattle using GnRH. (A) 5-day Cosynch+P4 protocol. The interval from P4 device removal to FTAI is 66-72 h in heifers and $72 \mathrm{~h}$ in cows. If tail-paint or patches are used for estrus detection, FTAI begins at $60 \mathrm{~h}$ in all heifers with altered paint and those with the paint intact receive GnRH and are FTAI at $72 \mathrm{~h}$. A second $\mathrm{PGF}_{2} \alpha$ administered at the same time of the device removal or 6 to $12 \mathrm{~h}$ later is recommended in cows and $400 \mathrm{IU}$ of eCG may also be given in cows in postpartum anestrus. (B) Modified 5-day GnRH+P4 protocol. GnRH is not administered at $\mathrm{P} 4$-device insertion and only one $\mathrm{PGF}_{2} \alpha$ is required on Day 5. The recommended intervals from P4 device removal to FTAI are similar to those described previously.

Extending the proestrus period in estradiol/P4 based protocols

We have recently conducted a series of experiments to evaluate an estradiol/P4-based protocol with a prolonged proestrus interval, which has been named J-Synch (de la Mata and Bó, 2012). The treatment consists of the administration of $2 \mathrm{mg} \mathrm{EB}$ at the time of insertion of a $\mathrm{P} 4$ device that is removed 6 days later. A single dose of $\mathrm{PGF}_{2 \alpha}$ is given at device removal, and animals receive $\mathrm{GnRH}$ at the time of FTAI, 72 h later (Day 9).

A comparison of follicular and luteal dynamics between heifers treated with the 6-day J-Synch protocol and the conventional 7-day estradiol/P4-based protocol in which ECP was given at device removal (Day 7) showed that heifers in the J-Synch group ovulated $28 \mathrm{~h}$ later $(93.7 \pm 12.9 \mathrm{~h}$ after device removal; $\mathrm{P}<0.05)$ than those in the conventional treatment $(65.0 \pm 13.7 \mathrm{~h}$ after device removal). Although the diameter of the preovulatory follicle did not differ between groups, the growth rate of the dominant follicle from $\mathrm{P} 4$ device removal to ovulation was greater in heifers in the $\mathrm{J}$ Synch group $(1.3 \pm 0.4 \mathrm{~mm} /$ day $)$ than those in the conventional group $(1.0 \pm 0.4 ; \mathrm{P}<0.05)$. Furthermore, serum $\mathrm{P} 4$ concentrations on Days 6 to 12 after ovulation were greater in heifers in the J-Synch group than in those in the conventional group $(\mathrm{P}<0.05)$. Immunohistochemistry and real-time PCR of biopsies taken on Day 6 after ovulation suggested that heifers with the prolonged proestrus (J-Synch) had a more mature uterine environment for embryo development. This notion was based on lower $(\mathrm{P}<0.05)$ staining intensity of the endometrial $\mathrm{P} 4$ receptors (PGR) in the intercaruncular uterine stroma and a tendency $(\mathrm{P}<0.08)$ for lower PR mRNA and $\mathrm{IGF}_{1}$ mRNA in heifers treated with the J-Synch protocol than in those treated with the conventional protocol (de la Mata et al., 2018).

Several field trials were conducted to compare $\mathrm{P} / \mathrm{AI}$ in heifers treated with the J-Synch protocol or the conventional estradiol/P4-based protocol (reviewed in Bó et al., 2016). In this series of experiments heifers in the J-Synch group were FTAI at the time of GnRH administration (i.e. $72 \mathrm{~h}$ after $\mathrm{P} 4$ device removal), whereas those in the conventional group were FTAI 54 $\mathrm{h}$ after device removal and ECP treatment. Although in the first experiment performed during the winter with heifers losing weight, $\mathrm{P} / \mathrm{AI}$ was lower in heifers in the $\mathrm{J}$ Synch group, in two experiments performed in the spring, with heifers gaining weight, the cumulative P/AI were higher in those treated with the J-Synch protocol than in those treated with the conventional estradiol/P4based protocol. The contradictory results in the previous experiments was attributed to lower estradiol concentrations in the heifers that were losing weight in the winter compared to those gaining weight in the spring (Perry, 2017a). As it was mentioned earlier, high estradiol concentrations in the proestrous period have 
been associated with a more appropriate uterine environment, higher luteal phase $\mathrm{P} 4$ concentrations and a lower incidence of embryo loss (Perry, 2017b). Therefore, the administration of ECP in the heifers in the conventional protocol in the winter may have higher P/AI through higher exposure to estradiol and the ovulation of smaller follicles (Jinks et al., 2013). Conversely, the heifers treated in the spring while gaining weight may have had larger estradiol-producing follicles, thus no additional estradiol was needed to achieve high fertility (Perry, 2017a).

In order to avoid the confounding effects of nutrition on fertility in the J-Synch protocol, a study was designed to evaluate the effect of adding $300 \mathrm{IU}$ of eCG at device removal to stimulate the growth of the dominant follicle on P/AI (Bó et al., 2016). The addition of $300 \mathrm{IU}$ eCG at the time of P4 device removal resulted in higher P/AI $(57.1 \% ; 739 / 1295)$ as compared to those that did not receive eCG $(53.1 \% ; 692 / 1303)$. In another experiment, all heifers received $300 \mathrm{IU}$ eCG at device removal but half were treated with the J-Synch protocol and the other half with the conventional estradiol/P4 based protocol with ECP at device removal. Again, P/AI was significantly higher in the J-Synch group (56.1\%; $631 / 1,125)$ than in the conventional treatment group $(50.7 \% ; 620 / 1,224)$. The J-Synch protocol was also tested in 945 recipients receiving in vitro-produced embryos (Menchaca et al., 2015). Pregnancy rate following embryo transfer 7 or $8 \mathrm{~d}$ after GnRH (J-Synch $+400 \mathrm{IU}$ eCG) or 9 or $10 \mathrm{~d}$ after ECP (conventional + $400 \mathrm{IU}$ eCG) was higher $(\mathrm{P}<0.01)$ in recipients synchronized with the J-Synch protocol $(49.3 \%)$ than the conventional estradiol/P4-based protocol (40.9\%). In conclusion, the strategy for extending proestrus significantly improved fertility in Bos taurus heifers. This improvement was considered to be due to a more competent $\mathrm{CL}$ that produced greater P4 concentrations in the ensuing luteal phase after AI and a uterine environment that may favor embryo development.

Although, more research is required in Bos indicus heifers, in one study, P/AI did not differ in Nelore and Nelore crossbred heifers treated with the JSynch protocol or with the conventional protocol (both with $200 \mathrm{IU}$ eCG at device removal; Motta et al., 2016). A similar approach of a prolonged proestrus and FTAI at $72 \mathrm{~h}$ after device removal, but by giving $1 \mathrm{mg}$ EB 36 $\mathrm{h}$ after device removal instead of $\mathrm{GnRH}$ at the time of FTAI was evaluated in Brahman heifers (Edwards et al., 2015). P/AI was significantly higher in heifers treated with the prolonged proestrus protocol than those treated with the conventional 8-day protocol in one farm, but no differences were detected in two other farms.

\section{Proestrus length, estrus expression and GnRH treatments}

An experiment was designed to evaluate the effect of the length of proestrus (i.e. interval from P4 device removal to GnRH and FTAI) on fertility in heifers (Núñez-Olivera et al., 2016). Angus and Angus crossbred heifers $(n=911)$ received a $\mathrm{P} 4$ releasing device containing 0.5 g P4 (DIB 0.5, Zoetis, Argentina) and $2 \mathrm{mg}$ of EB (Gonadiol, Zoetis) on Day 0. At the time of P4 device removal (Day 6), $500 \mu \mathrm{g}$ of cloprostenol (Ciclase DL, Zoetis) and $300 \mathrm{IU}$ of eCG (Novormon, Zoetis) were administered IM. Heifers were then allocated in three groups to receive $\mathrm{GnRH}$ (100 $\mu \mathrm{g}$ gonadorelin acetate; Gonasyn GDR, Zoetis) and FTAI at 48, 60 or $72 \mathrm{~h}$ later. The diameter of the largest follicle (measured by ultrasonography) and estrus expression using tail-paint were recorded in a subset of heifers $(n=525)$ at the time of FTAI. Results are shown in Table 1. The largest follicle was smaller $(\mathrm{P}<0.05)$ when $\mathrm{GnRH} / \mathrm{FTAI}$ was performed at $48 \mathrm{~h}$ compared with 60 or $72 \mathrm{~h}$. In addition, more heifers tended to display estrus by $72 \mathrm{~h}(\mathrm{P}<0.1)$ than 48 or $60 \mathrm{~h}$. Although the overall $\mathrm{P} / \mathrm{AI}$ tended to be greater $(\mathrm{P}<0.1)$ in heifers inseminated at $72 \mathrm{~h}$ than at 48 or $60 \mathrm{~h}, \mathrm{P} / \mathrm{AI}$ was significantly greater $(\mathrm{P}<0.05)$ among cycling heifers (i.e. with a CL on Day 0) in those FTAI at $72 \mathrm{~h}$ than in those FTAI at 48 or 60 . In non-cycling heifers, P/AI did not differ among groups (58.9\%, 247/419). Among the heifers showing estrus at the time of FTAI, $\mathrm{P} / \mathrm{AI}$ was higher $(\mathrm{P}<0.05)$ in those FTAI at $72 \mathrm{~h}$ $(70.1 \%, 96 / 137)$ than in those FTAI at $60 \mathrm{~h}(56.7 \%$, $68 / 120 ; \mathrm{P}<0.05)$, while $48 \mathrm{~h}$ was intermediate $(63.9 \%$, 78/122).

Based on the findings of the previous studies, it was proposed that heifers that manifest estrus earlier could be inseminated earlier without affecting P/AI, but it was needed to determine the optimum time for FTAI in those not showing estrus. To answer this question, 1,283 Angus and Hereford crossbred heifers were treated with the J-Synch protocol as described above and all heifers were tail-painted at $\mathrm{P} 4$ device removal. Heifers received GnRH/FTAI at either 60 or $72 \mathrm{~h}$, regardless of paint removal. P/AI was higher in those that showed estrus prior to FTAI than in those that did not regardless of insemination time $(53.6 \%, 542 / 1,012$ vs. $45.0 \%, 122 / 271$, respectively, $\mathrm{P}<0.05)$. The $\mathrm{P} / \mathrm{AI}$ in heifers that were in estrus by $60 \mathrm{~h}$ was similar whether the FTAI/GnRH was performed at 60 or $72 \mathrm{~h}$. However, in those not showing estrus, P/AI was higher when the FTAI/GnRH was performed at $72 \mathrm{~h}(52 \%, 45 / 143)$ than at $60 \mathrm{~h}(37 \%, 47 / 128)$. The practical implication of this result is that when large herds are synchronized (i.e. 400 to 500 head), the device could be removed in the afternoon of Day 6 and FTAI begins at $60 \mathrm{~h}$ (Day 9 $\mathrm{AM})$ in all heifers with altered paint as they come through the chute; those with the paint intact could be separated off to receive GnRH/FTAI in the afternoon of Day 9 (i.e. around or after $72 \mathrm{~h}$ ).

The second question that was raised was the necessity to administer GnRH in those heifers that had already shown estrus prior to FTAI. An experiment was performed with 1,879 Angus heifers that were treated similarly to the previous study. All heifers displaying estrus at $60 \mathrm{~h}(85 \%, 1594 / 1879)$ were FTAI at that time, but GnRH was administered to only half. The heifers not displaying estrus at $60 \mathrm{~h}$ received GnRH/FTAI at $72 \mathrm{~h}$. $\mathrm{P} / \mathrm{AI}$ in the heifers that had manifested estrus by $60 \mathrm{~h}$ did not differ whether they received or did not receive GnRH (56.2\% 451/802, vs. 58.6\% 464/792, respectively), but $\mathrm{P} / \mathrm{AI}$ was higher than in those not showing estrus by $60 \mathrm{~h}$ 
and receiving FTAI/GnRH at $72 \mathrm{~h}(40.4 \%, 15 / 285 ; \mathrm{P}<$ $0.05)$. Therefore, with the use of tail-paint the cost of treatment could be reduced by giving $\mathrm{GnRH}$ to only the $25-30 \%$ of the heifers not showing estrus. The recommended protocol for FTAI is shown in Fig. 2.

Most of the experiments with the J-Synch protocol were performed in heifers and more information is needed about the performance of this protocol in lactating beef cows. Preliminary information using the J-Synch in non-lactating cows (i.e. after early weaning at 60 days postpartum) indicated P/AI were comparable to those reported in heifers (62.5\%; $1,188 / 1,900)$, with higher P/AI in cows showing estrus by the time of FTAI (Menchaca et al., 2017). As with heifers, it is possible to avoid the use of GnRH at the time of the FTAI if tail-paint is used to determine the expression of estrus.

Only one study has been performed with the JSynch protocol in suckled beef cows, with lower P/AI than in cows treated with the conventional estradiol/P4based 7-day protocol (Bó et al., 2017), raising questions about the optimal period of P4 device insertion (6 or 7 days), the interval from device removal to ovulation (to determine the time for FTAI) and the requirement of ECP or GnRH to induce ovulation. More studies are underway to answer these questions.

Table 1. Diameter of the largest follicle, estrus expression and P/AI in beef heifers synchronized with the J-Synch protocol and received GnRH and were fixed-time AI at different intervals from the removal of the P4 releasing device.

\begin{tabular}{|c|c|c|c|c|}
\hline & $\begin{array}{c}\text { Follicular diameter } \\
\text { at FTAI } \\
(\mathrm{mm}) \\
\end{array}$ & $\begin{array}{c}\text { Heifers in estrus } \\
\text { at FTAI } \\
(\%)\end{array}$ & $\begin{array}{c}\text { P/AI in cycling } \\
\text { heifers* } \\
(\%)\end{array}$ & $\begin{array}{c}\text { Overall } \\
\text { P/AI } \\
(\%) \\
\end{array}$ \\
\hline GnRH/FTAI $48 \mathrm{~h}$ & $\begin{array}{c}12.2 \pm 0.1^{\mathrm{a}} \\
(\mathrm{n}=179)\end{array}$ & $\begin{array}{c}68.2^{\mathrm{a}} \\
(122 / 179)\end{array}$ & $\begin{array}{c}67.7 \%{ }^{\mathrm{a}} \\
(107 / 158)\end{array}$ & $\begin{array}{c}63.6 \%{ }^{\mathrm{c}} \\
(196 / 308)\end{array}$ \\
\hline GnRH/FTAI $60 \mathrm{~h}$ & $\begin{array}{l}12.8 \pm 0.1^{b} \\
(\mathrm{n}=168)\end{array}$ & $\begin{array}{c}71.4 \% \mathrm{o}^{\mathrm{a}} \\
(120 / 168)\end{array}$ & $\begin{array}{c}68.3 \%{ }^{\mathrm{a}} \\
(110 / 161)\end{array}$ & $\begin{array}{c}63.1 \% \%^{\mathrm{c}} \\
(183 / 290)\end{array}$ \\
\hline GnRH/FTAI $72 \mathrm{~h}$ & $\begin{array}{c}12.9 \pm 0.2^{b} \\
(\mathrm{n}=178)\end{array}$ & $\begin{array}{c}77.0 \% \mathrm{o}^{\mathrm{a}} \\
(137 / 178)\end{array}$ & $\begin{array}{c}77.5 \%{ }^{\mathrm{b}} \\
(134 / 173)\end{array}$ & $\begin{array}{c}70.0 \%{ }^{\mathrm{d}} \\
(219 / 313)\end{array}$ \\
\hline
\end{tabular}

${ }^{a b}$ Denotes significant $(\mathrm{P}<0.05)$ differences between treatment groups. ${ }^{\text {cd }}$ Denotes a tendency $(\mathrm{P}<0.1)$ for higher overall P/AI in heifers inseminated at $72 \mathrm{~h}$. *Heifers with a CL detected by ultrasonography at the time of P4 device insertion.

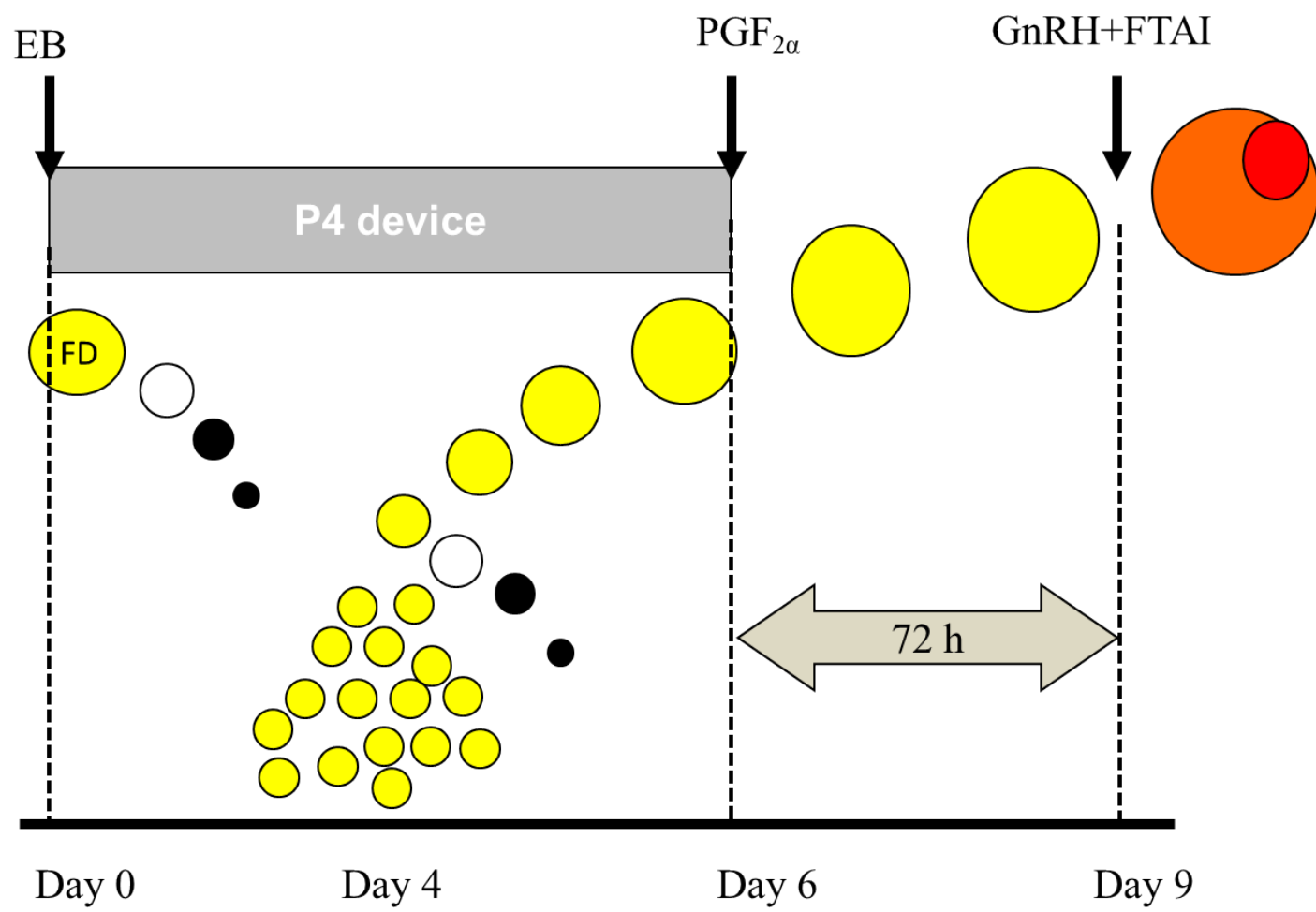

Figure 2. Estradiol/P4-based protocol with prolonged proestrus (J-Synch) in beef heifers. For FTAI without estrus detection, heifers receive GnRH and are inseminated 66-72 h after P4-device removal. If tail-paint or patches are used for estrus detection, FTAI begins at $60 \mathrm{~h}$ in all heifers with altered paint and those with the paint intact receive GnRH and are FTAI at $72 \mathrm{~h}$. eCG (300 IU in heifers and $400 \mathrm{IU}$ in cows) may also be given in those animals in anestrus. 
Protocols for fixed-time AI using sexed-sorted semen

The use of sexed-sorted semen has created great interest in the insemination of dairy heifers over the past 20 years; however, the widespread use of sexed semen was somewhat limited because fertility was compromised, especially with FTAI (DeJarnette et al., 2011). However, the sorting procedure has been improved and a new product called SexedULTRA ${ }^{\mathrm{TM}}$, with the option of increasing the number of sperm from $2.1 \times 10^{6}$ to $4 \times 10^{6}$ sperm per straw has been launched (Vishwanath, 2015).

A series of experiments were designed to determine $\mathrm{P} / \mathrm{AI}$ using modifications of the existing estradiol/P4-based protocols for sexed semen. Two experiments were carried out using suckled Nelore cows that received the conventional protocol for FTAI as follows: $2 \mathrm{mg} \mathrm{EB}+\mathrm{P} 4$ device on Day 0, removal of the device and $\mathrm{PGF}_{2 \alpha}+300 \mathrm{IU}$ of eCG $+1 \mathrm{mg}$ of ECP on Day 8 and FTAI $60 \mathrm{~h}$ after P4 device removal (Baruselli et al., 2017b). In the first experiment, 796 cows were inseminated with female sexed-selected semen and nonsexed (Control) semen from three different Nelore bulls. The experimental groups were: 1) non-sexed semen with $20 \times 10^{6}$ sperm per dose; 2) Legacy (previous method of sexing), sexed semen with $2.1 \times 10^{6}$ sperm per dose; 3) SexedULTRA with $2.1 \times 10^{6}$ sperm per dose and 4) SexedULTRA 4.0, sexed semen with $4.0 \times 10^{6}$ sperm per dose. No differences were detected between sires $(\mathrm{P}=0.15)$. Although $\mathrm{P} / \mathrm{AI}$ was highest $(\mathrm{P}<0.05)$ in cows in the non-sexed semen group $(56 \%, 112 / 199)$, cows in the SexedULTRA 4.0 group had higher P/AI $(43 \%, 86 / 200)$ than those in the Legacy 2.1 group $(28 \%$, $58 / 206)$. In cows inseminated with the SexedULTRA 2.1 semen $\mathrm{P} / \mathrm{AI}$ was intermediate $(38 \%, 72 / 191)$ and not different than the other groups inseminated with sexed semen. In the second experiment, 613 cows were treated as those in the first experiment and inseminated with semen from three Angus sires. The experimental groups were 1) non-sexed semen $\left(20 \times 10^{6}\right.$ sperm); 2) SexedULTRA 4.0 and 3) SexedULTRA Pure 4.0 (dead sperm were removed). A subgroup of 431 cows was tail-painted for estrus determination at the time of FTAI. $\mathrm{P} / \mathrm{AI}$ among sires did not differ $(\mathrm{P}=0.12)$. Overall $\mathrm{P} / \mathrm{AI}$ was not different among groups (non-sexed semen: 51.2\%, 107/209; SexedULTRA 4.0: 42.0\%; 84/200 and
SexedULTRA Pure 43.1\%; 88 / 204; $\mathrm{P}=0.10$; Baruselli et al., 2017b). Furthermore, in the subgroup of animals in which estrus was recorded there was a significant interaction between type of semen and expression of estrus $(\mathrm{P}<0.01)$. In cows showing estrus, $\mathrm{P} / \mathrm{AI}$ was not different between cows inseminated with sexed or nonsexed semen (Table 2). Conversely, in cows not showing estrus $\mathrm{P} / \mathrm{AI}$ was higher $(\mathrm{P}<0.05)$ for those inseminated with non-sexed semen and those inseminated with SexedULTRA Pure, whereas P/AI in those inseminated with SexedULTRA was intermediate and not different from the other two groups. The recommended protocol for FTAI with sexed-sorted semen is shown in Fig. 3.

Another study was carried out to evaluate P/AI in heifers treated with the J-Synch protocol and inseminated with SexedULTRA semen (Huguenine et al., 2017, unpublished). Angus and Angus crossbred beef heifers $(\mathrm{n}=850)$ were treated with the J-Synch protocol with $300 \mathrm{IU}$ eCG at P4 device removal (Day 6) and were tail-painted for estrus determination. The heifers with the paint-rubbed off at 60 or $72 \mathrm{~h}$ after device removal were randomly subdivided into two subgroups to be inseminated at $72 \mathrm{~h}$ with female SexedULTRA 4.0 semen or with non-sexed semen from the same four Angus sires. Heifers that did not showed estrus by $72 \mathrm{~h}$ received GnRH at that time and were inseminated at $84 \mathrm{~h}$ with the same two types of semen. The protocol is shown in Fig. 4 and the results are shown in Table 3. There were $72.7 \%(618 / 850)$ of heifers in estrus at 60 and $72 \mathrm{~h}$ and the overall P/AI was $54.0 \%(459 / 850)$ regardless of expression of estrus. There was a significant $(\mathrm{P}<0.01)$ effect of semen type (Table 3), time of $\mathrm{AI}$ and sire on $\mathrm{P} / \mathrm{AI}$, but no interactions. P/AI were $64.1 \%(223 / 348)$ for heifers in estrus at $60 \mathrm{~h}$ and inseminated at $72 \mathrm{~h}, 51.8 \%$ (140/270) for those in estrus and inseminated at $72 \mathrm{~h}$, and $40.9 \%$ $(95 / 232)$ for those not in estrus by $72 \mathrm{~h}$ and inseminated at $84 \mathrm{~h}$ after $\mathrm{P} 4$ device removal. Regarding sires, P/AI ranged from $40.5 \%$ to $67.8 \%$ with non-sexed semen and $26.5 \%$ to $59.3 \%$ with SexedULTRA semen. In summary, protocols designed for FTAI in cows and heifers can be adapted for sexed-sorted semen. Although, P/AI are lower than those obtained with nonsexed semen, delaying the time of AI or limiting the AI to those animals showing estrus would result in $\mathrm{P} / \mathrm{AI}$ between 40 and $50 \%$ or even higher.

Table 2. Pregnancy rates in lactating Nelore cows inseminated with sexed-sorted (SexedULTRA ${ }^{\mathrm{TM}}$ ) or non-sexed semen according to the expression estrus (reading of paint-stick) and time of insemination (AI) after the removal of the progesterone releasing device.

\begin{tabular}{lcccc}
\hline & $\mathrm{n}$ & $\begin{array}{c}\text { Estrus } 60 \mathrm{~h} \\
\text { AI } 60 \mathrm{~h}\end{array}$ & $\begin{array}{c}\text { No estrus at } 60 \mathrm{~h} \\
\text { AI 60 h }\end{array}$ & Total \\
\hline SexedULTRA $\left(4 \times 10^{6}\right.$ sperm) & 138 & $50 / 94$ & $14 / 44$ & $64 / 138$ \\
& & $(53.1 \%)$ & $(31.8 \%)^{\mathrm{ab}}$ & $(46.4 \%)$ \\
SexedULTRA Pure $\left(4 \times 10^{6}\right.$ sperm) & 144 & $54 / 102$ & $9 / 42$ & $63 / 144$ \\
& & $(52.9 \%)$ & $(21.4 \%)^{\mathrm{bc}}$ & $(43.8 \%)$ \\
Non-sexed (20x10 $10^{6}$ sperm) & 149 & $57 / 110$ & $18 / 39$ & $75 / 149$ \\
& & $(51.8 \%)$ & $(46.2 \%)^{\mathrm{c}}$ & $(50.3 \%)$ \\
\hline
\end{tabular}

${ }^{\text {abc }}$ Denotes differences in P/AI between sexed-sorted or non-sexed semen in cows not showing estrus $(\mathrm{P}<0.05)$. 


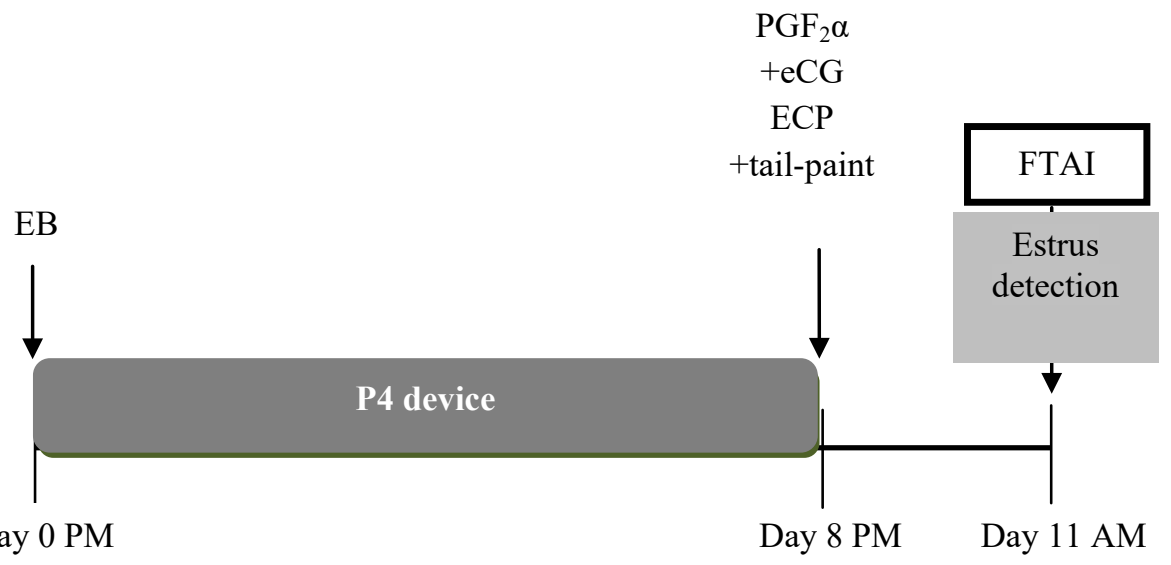

$(60 \mathrm{~h})$

Figure 3. Conventional estradiol/P4-based protocol for FTAI with sexed-sorted semen. Tail-paint or patches are used to detect those animals in estrus $60 \mathrm{~h}$ after P4-device removal. Animals in estrus by $60 \mathrm{~h}$ are inseminated with sexed-sorted semen whereas those animals not in estrus by $60 \mathrm{~h}$ receive $\mathrm{GnRH}$ and are inseminated at the same time with sexed-sorted or non-sexed semen.

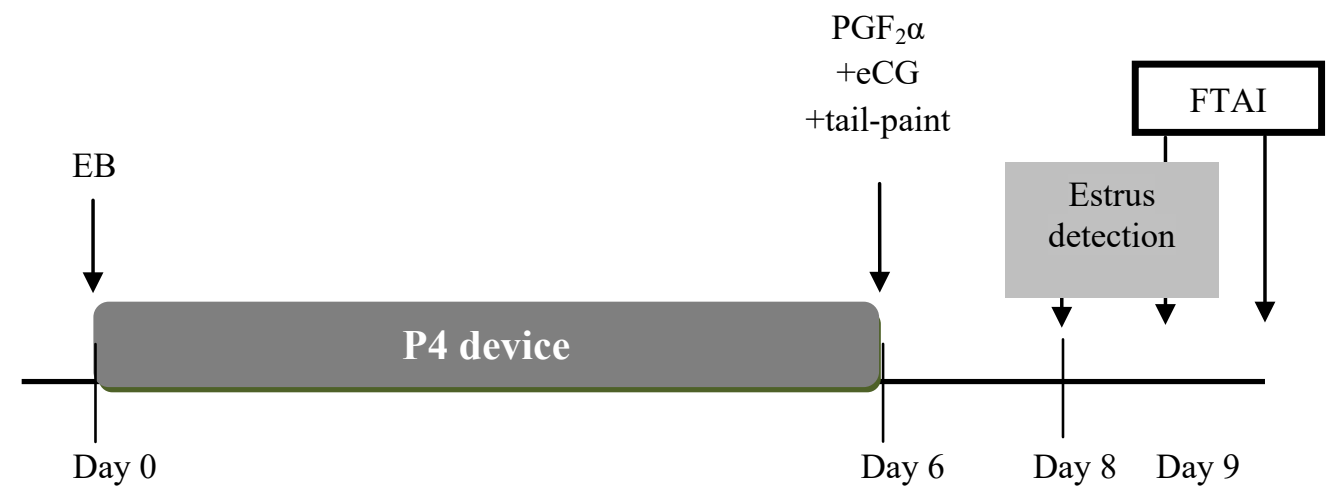

(60 h) (72 h and $84 \mathrm{~h})$

Figure 4. Alternative estradiol/P4 based protocol with prolonged proestrus for FTAI beef heifers with sexed-sorted semen. Tail-paint or patches are used to detect those heifers in estrus at 60 and $72 \mathrm{~h}$ after P4-device removal. Heifers in estrus at 60 and $72 \mathrm{~h}$ are inseminated at $72 \mathrm{~h}$ with sexed-sorted semen. Heifers not in estrus by $72 \mathrm{~h}$ receive GnRH and are inseminated at $84 \mathrm{~h}$ with sexed sorted or non-sexed semen.

Table 3. Pregnancy rates in Angus heifers inseminated with sexed-sorted (SexedULTRA ${ }^{\mathrm{TM}}$ ) or non-sexed semen according to the expression estrus (reading of tail-paint) and time of insemination (AI) after the removal of the progesterone releasing device.

\begin{tabular}{lccccc} 
& $\mathrm{n}$ & $\begin{array}{c}\text { Estrus 60 } \mathrm{h} \\
\text { AI 72 }\end{array}$ & $\begin{array}{c}\text { Estrus 72 } \mathrm{h} \\
\text { AI 72 } \mathrm{h}\end{array}$ & $\begin{array}{c}\text { No estrus at 60 or 72 } \mathrm{h} \\
\text { AI 84 h }\end{array}$ & Total \\
\hline SexedULTRA & 426 & $104 / 176$ & $61 / 134$ & $45 / 116$ & $210 / 426$ \\
$\left(4 \times 10^{6}\right.$ sperm) & & $(59.0 \%)$ & $(45.5 \%)^{\mathrm{a}}$ & $(38.8 \%)$ & $(49.3 \%)^{\mathrm{a}}$ \\
Non-sexed & 424 & $119 / 172$ & $79 / 136$ & $49 / 116$ & $247 / 424$ \\
$\left(25 \times 10^{6}\right.$ sperm) & & $(69.2 \%)$ & $(58.0 \%)^{\mathrm{b}}$ & $(42.2 \%)$ & $(58.3 \%)^{\mathrm{b}}$ \\
\hline
\end{tabular}

${ }^{\mathrm{ab}}$ Denotes differences in $\mathrm{P} / \mathrm{AI}$ between sexed-sorted or non-sexed semen $(\mathrm{P}<0.05)$.

\section{Re-synchronization treatments}

With the advent of FTAI in beef herds, producers have been seeking strategies that can be implemented to obtain the highest possible number of cows pregnant through AI early in the breeding season. Several approaches have been developed over the years; however, most require estrus observations or an interval of approximately 40 days between the first and second FTAI (reviewed in Bó et al., 2016 and Baruselli et al., 2017a). In order to be able to inseminate non-pregnant cows as early as possible, re-synchronization treatments must start earlier than pregnancy diagnosis. One protocol was developed in which a re-used device impregnated with $1 \mathrm{~g}$ of $\mathrm{P} 4$ (i.e. previously used in the first synchronization) was re-inserted on Days 14-16 
after the first AI and is removed on Day 23 at the time that GnRH was administered. Pregnancy diagnosis is performed on Day 30 and those that are found to be non-pregnant receive $\mathrm{PGF}_{2 \alpha}$ combined with either 0.5 $\mathrm{mg}$ ECP at that time or simply GnRH at the time of FTAI on Day 32. P/AI for the first and second FTAI and the overall $\mathrm{P} / \mathrm{AI}$ in a field trial involving 6,431 beef cows and heifers were $57 \%, 51 \%$ and $79 \%$, respectively (Bó et al., 2016).

Two new protocols for re-synchronization are called Resynch 22 and Resynch 14 (Baruselli et al., 2017a). In the Resynch 22, cows receive $2 \mathrm{mg}$ EB (Pessoa et al., 2015) and heifers $1 \mathrm{mg}$ EB (Sá Filho et al., 2014) at P4 device insertion on Day 22. Pregnancy diagnosis is performed at device removal (Day 30) and non-pregnant animals also receive $\mathrm{PGF}_{2 \alpha}$ and ECP and are inseminated on Day 32. The Resynch 14 protocol involves the use of color Doppler ultrasonography for the detection of pregnancy based on the vascularization and size of the CL on Day 22 after the first AI (Siqueira et al., 2013; Pugliesi et al., 2014, 2017). For Resynch 14 the initial treatment starts 14 days after FTAI with the re-insertion of a re-used device and the administration of $100 \mathrm{mg}$ P4 IM (Rezende et al., 2016) to avoid the possible luteolytic effect of EB (Vieira et al., 2014). The new wave emerges $3.0 \pm 0.7$ days after $\mathrm{P} 4$ administration in Nelore cows (Rezende et al., 2016); thus cows are scanned with Doppler ultrasonography for pregnancy at device removal (Day 22) and non-pregnant animals receive $\mathrm{PGF}_{2 \alpha}$ and $\mathrm{ECP}$ and are inseminated on Day 24. In a recent study, similar P/AI were observed for Resynch 22 and Resynch 14 groups following the first FTAI $(48 \%$ vs 53\%; $\mathrm{P}=0.57)$ and resynchronization $(56 \%$ vs $51 \%$; $\mathrm{P}=0.37)$, respectively. However, the Resynch 14 reduced the interval between FTAI, which resulted in a 21-day P/AI of $87.5 \%$ compared to $66 \%$ with the Resynch 22 (Penteado et al., 2016). In a more recent field trail, the use of three consecutive FTAI with the Resynch 22 protocol had a similar overall pregnancy rate $(87.8 \%, 663 / 755)$ as that achieved using clean-up bulls after two FTAI using Resynch $22(87.7 \%, 263 / 300)$ and greater pregnancy rate than one FTAI followed by bull exposure $(77.1 \%$, 347/450; Crepaldi et al., 2017). In conclusion, with the existing re-synchronization programs it is now possible to breed beef cows exclusively with FTAI, eliminating the need for estrus detection and clean-up bulls.

\section{Summary and conclusions}

Protocols for FTAI have allowed the widespread use AI in South-America, with the possibility of obtaining $\mathrm{P} / \mathrm{AI}$ of $50 \%$ or more with a single insemination. The addition of eCG at P4-device removal to stimulate the growth of the ovulatory follicle has been especially useful in increasing P/AI in cows experiencing postpartum anestrus. New treatment protocols that do not require the use of estradiol or GnRH shortly after P4 device removal and allow for a longer proestrus period prior to insemination are alternatives for increasing fertility to FTAI; however, the animals must be in optimal nutritional conditions to achieve high P/AI. Furthermore, FTAI treatments combined with estrus detection using tail-paint or heatdetection patches permits the use of sexed-sorted semen with acceptable P/AI. Finally, early pregnancy diagnosis with ultrasonography can be easily implemented in beef herds in order to perform sequential FTAI without estrus detection, resulting in pregnancy rates that are similar or higher than obtained with clean-up bulls, maximizing the use of the improved genetics through AI

\section{Acknowledgments}

Research was supported by FONCYT (PICT 2017-4550), Universidad Nacional de Villa María, Zoetis and Sexing Technologies from Argentina, and ANII, Syntex Uruguaya SA and Fundaciba from Uruguay.

\section{References}

Baruselli PS, Reis EL, Marques MO, Nasser LF, Bó GA. 2004. The use of treatments to improve reproductive performance of anestrus beef cattle in tropical climates. Anim Reprod Sci, 82-83:479-486.

Baruselli PS, Sá Filho MF, Ferreira RM, Sales JNS, Gimenes LU, Vieira LM, Mendanha MF, Bó GA. 2012. Manipulation of follicle development to ensure optimal oocyte quality and conception rates in cattle. Reprod Domet Anim, 47(Suppl 4):134-141.

Baruselli PS, Ferreira RM, Colli MHA, Elliff FM, Sá Filho MF, Vieira L, Gonzales de Freitas B. 2017a. Timed artificial insemination: current challenges and recent advances in reproductive efficiency in beef and dairy herds in Brazil. Anim Reprod, 14:558-571.

Baruselli PS, Campos Filho EP, Crepaldi GA, Panazzollo SG, Zanatta GM, Colli MHA, Mingoti RD, Cruz GC, Castro MW. 2017b. New strategies to improve pregnancy rate at TAI using sex-sorted semen. Anim Reprod, 14:711. (Abstract).

Binelli M, Pugliesi G, Hoeck VV, Sponchiado M, Ramos RS, Oliveira ML, França MR, D`Alexandri FL, Mesquita FS, Membrive CMB. 2014. The role of proestrus on fertility and postovulatory uterine function in the cow. Anim Reprod, 11:246-253.

Bó GA, Baruselli PS, Mapletoft RJ. 2013. Synchronization techniques to increase the utilization of artificial insemination in beef and dairy cattle. Anim Reprod, 10:137-142.

Bó GA, Baruselli PS. 2014. Synchronization of ovulation and fixed-time artificial insemination in beef cattle. Animal, 8:144-150.

Bó GA, de la Mata JJ, Baruselli PS, Menchaca A. 2016. Alternative programs for synchronizing and resynchronizing ovulation in beef cattle. Theriogenology, 86:388-396.

Bó GA, Huguenine E, de la Mata JJ, Menchaca A. 2017. FTAI programs using the J-synch protocol in suckled cows. Proceedings 12th International Symposium on Animal Reproduction. Institute of Animal Reproduction Cordoba (IRAC). Cordoba, Argentina, pp. 277-284. 
Bridges GA, Helser LA, Grum DE, Mussard ML, Gasser CL, Day ML. 2008. Decreasing the interval between GnRH and PGF2 $\alpha$ from 7 to 5 days and lengthening proestrus increases timed-AI pregnancy rates in beef cows. Theriogenology, 69:843-851.

Bridges GA, Ahola JK, Brauner C, Cruppe LH, Currin JC, Day ML, Gunn PJ, Jaeger JR, Lake SL, Lamb GC, Marquezini GHL, Peel RK, Radunz AE, Stevenson JS, Whittier WD. 2012. Determination of the appropriate delivery of prostaglandin F2 $\alpha$ in the five-day CO-Synch + controlled intravaginal drug release protocol in suckled beef cows. J Anim Sci, 90:4814-4822.

Bridges GA, Day ML, Geary TW, Cruppe LH. 2013. Deficiencies in the uterine environment and failure to support embryonic development. J Anim Sci, 91:30023013.

Bridges GA, Mussard ML, Hesler LA, Day ML. 2014. Comparison of follicular dynamics and hormone concentrations between the 7-day and 5-day CO-Synch + CIDR program in primiparous beef cows. Theriogenology, 81:632-638.

Colazo MG, Ambrose DJ. 2011. Neither duration of progesterone insert nor initial GnRH treatment affected pregnancy per timed-insemination in dairy heifers subjected to a Co-synch protocol. Theriogenology, 76:578-588.

Colazo MG, Whittaker PR, Bignell DJ, Mapletoft RJ. 2017. Evaluation of a modified GnRH-based timed artificial insemination protocol associated with estrus detection in cyclic beef heifers inseminated with sexedselected semen. Reprod Fertil Dev, 29:112. (Abstract).

Crepaldi GA, Freitas BG, MIngoti RD, Colli MHA, Gonçales Junior WA, Ferreira RM, Baruselli PS. 2017. Reproductive efficiency of Nelore cows submitted to three different reproductive strategies in a 64 days breeding season. Anim Reprod, 14:698. (Abstract).

Cruppe LH, Day ML, Abreu FM, Kruse S, Lake SL, Biehl MV, Cipriano RS, Mussard ML, Bridges GA. 2014. The requirement of $\mathrm{GnRH}$ at the beginning of the five-day CO-Synch + controlled internal drug release protocol in beef heifers. J Anim Sci, 92:4198-4203.

Day ML. 2015. State of the art of GnRH-based timed AI in beef cattle. Anim Reprod, 12:473-478.

de la Mata JJ, Bó GA. 2012. Estrus synchronization and ovulation using protocols with estradiol benzoate and $\mathrm{GnRH}$ and reduced periods of insertion of a progesterone releasing device in beef heifers. Taurus, 55:17-23.

de la Mata JJ, Núñez-Olivera F, Cuadro F, Bosolasco D, de Brund V, Meikle A, Bó GA Menchaca A. 2018. Impact of extending the proestrus length in an oestradiol and progesterone-based oestrus synchronization program on follicular and luteal development, uterine gene expression, and protein localization, and pregnancy rates in beef heifers. Reprod Fertil Dev. Doi.org/10.1071/RD17473

DeJarnette JM, Leach MA, Nebel RL, Marshall CE, McCleary CR, Moreno JF. 2011. Effects of sexsorting and sperm dosage on conception rates of Holstein heifers: Is comparable fertility of sex-sorted and conventional semen plausible? $J$ Dairy Sci, 94:3477-3483.
Edwards AA, Boe-Hansen GB, Satake N, Chandra K, McGowan MR. 2015. A field investigation of a modified intravaginal progesterone releasing device and oestradiol benzoate based ovulation synchronisation protocol designed for fixed-time artificial insemination of Brahman heifers. Anim Reprod Sci, 160:105-111.

Ferraz Jr MVC, Pires AV, Biehl MV, Santos MH, Barroso JPR, Goncalves JRS, Sartori R, Day ML. 2016. Comparison of two timed artificial insemination system schemes to synchronize estrus and ovulation in Nellore cattle. Theriogenology, 86:1939-1943.

Geary TW, Whittier JC, Hallford DM, MacNeil MD. 2001. Calf removal improves conception rates to the Ovsynch and Co-synch protocols. J Anim Sci, 79:1-4.

Huguenine E, Peracchia S, Benitez R, Martini H, Cledou G, Bó GA, Callejas S. 2013. Effect of the utilization of 5-day CO-Synch protocols combined or not with eCG in suckled cows in postpartum anoestrus. Proceedings X Symposium on Animal Reproduction. Ed. GA Bó and M Caccia. Institute of Animal Reproduction Cordoba (IRAC), Córdoba, Argentina, pp.313. (Abstract).

Jinks EM, Smith MF, Atkins JA, Pohler KG, Perry GA, MacNeil MD, Roberts AJ, Waterman RC, Alexander LJ, Geary TW. 2013. Preovulatory estradiol and the establishment and maintenance of pregnancy in suckled beef cows. J Anim Sci, 91:11761185 .

Kasimanickam R, Asay M, Firth P, Whittier WD, Hall JB. 2012. Artificial insemination at $56 \mathrm{~h}$ after intravaginal progesterone device removal improved AI pregnancy rate in beef heifers synchronized with fiveday Co-Synch controlled internal drug release (CIDR) protocol. Theriogenology, 77:1624-1631.

Kasimanickam R, Day ML, Rudolph JS, Hall JB, Whitier WD. 2009. Two doses of prostaglandin improve pregnancy rates to timed-AI in a 5-day progesterone based synchronization protocol in beef cows. Theriogenology, 71:762-767.

Kasimanickam R, Firth P, Schuenemann GM, Whitlock BK, Gay JM, Moore DA, Hall JB, Whittier WD. 2014. Effect of the first GnRH and two doses of PGF $2 \alpha$ in a 5-day progesterone-based CO-Synch protocol on heifer pregnancy. Theriogenology, 81:797804.

Lamb GC, Stevenson JS, Kesler DJ, Garverick HA, Brown DR, Salfen BE. 2001. Inclusion of an intravaginal progesterone insert plus GnRH and prostaglandin $\mathrm{F} 2 \alpha$ for ovulation control in postpartum suckled beef cows. J Anim Sci, 79:2253-2259.

Madsen CA, Perry GA, Mogck CL, Daly RF, MAcNeil MD, Geary TW. 2015. Effects of preovulatory estradiol on embryo survival and pregnancy establishment in beef cows. Anim Reprod Sci, 158:96-103.

Marquezini GHL, Mercadante VRG, Olson KC, Jaeger JR, Perry GA, Stevenson JS, Lamb GC. 2013. Effects of equine chorionic gonadotropin on follicle development and pregnancy rates in suckled beef cows with or without calf removal. J Anim Sci, 91:1216-1224. Martinez MF, Kastelic JP, Adams GP, Cook RB, Olson WO, Mapletoft RJ. 2002. The use of progestins 
in regimens for fixed-time artificial insemination in beef cattle. Theriogenology, 57:1049-1059.

Menchaca A, Núñez R, Wijma R, García Pintos C, Fabini F, de Castro T. 2013. How fertility can be improved in fixed-time AI programs in beef cattle. Proceedings X Symposium on Animal Reproduction. Ed. GA Bó and M Caccia. Institute of Animal Reproduction Cordoba (IRAC), Córdoba, Argentina, pp.103-134.

Menchaca A, Dutra S, Carrau JM, Sapriza F, Salazar J, de la Mata JJ, Bó GA. 2015. Improvement of pregnancy rates by using the 6-day J-Synch protocol in recipient cows transferred with in vitro produced embryos. Anim Reprod, 12:653. (Abstract).

Menchaca A, Núñez-Olivera $\mathbf{R}$, García-Pintos $\mathbf{C}$, Cuadro F, Bosolasco D, Fabini F, Dutra S, de la Mata JJ, Bó GA. 2017. Effect of the prolongation of the proestrus in the fertility of the FTAI programs. Proceedings XII Symposium on Animal Reproduction. Institute of Animal Reproduction Cordoba (IRAC), Córdoba, Argentina, pp.191-216.

Motta JCL, Colli MHA, Penteado L, Bayeux BM, Mingoti RD, Bó GA, Lugo LC, Rezende RG, Baruselli PS. 2016. Pregnancy rate to FTAI in Nelore and crossbreed heifers submitted to J-Synch protocol (6 days). Anim Reprod, 13:401. (Abstract).

Núñez-Olivera $R$, de Castro T, García-Pintos $C$, Bó GA, Piaggio J, Menchaca A. 2014. Ovulatory response and luteal function after eCG administration at the end of a progesterone and estradiol-based treatment in postpartum anestrous beef cattle. Anim Reprod Sci, 146:111-116.

Núñez-Olivera R, Bó GA, Menchaca A. 2016. Association between proestrus length, preovulatory follicular diameter, estrus behavior and pregnancy rate in progesterone-estradiol based treatment J-Synch for FTAI in Bos taurus beef heifers. Proceedings 18th International Congress on Animal Reproduction (ICAR). Tours, France: Elsevier. pp. 477. (Abstract).

Penteado L, Rezende RG, Mingoti RD, Colli MHA, Sá Filho MF , Santos FB, Lemos Motta JC, Bayeux BM, Vieira LM, Baruselli PS. 2016. Pregnancy rate of Nelore cows submitted to resynchronization starting 14 or 22 days after prior FTAI. Anim Reprod, 13:450. (Abstract).

Perry GA. 2017a. Effects of nutritional management around the period of artificial insemination on embryo development and pregnancy rates in heifers. Proceedings XII Symposium on Animal Reproduction. Institute of Animal Reproduction Cordoba (IRAC), Córdoba, Argentina, pp.139-152.

Perry GA. 2017b. Effect of follicular maturity on the establishment of pregnancy. Proceedings XII Symposium on Animal Reproduction. Institute of Animal Reproduction Cordoba (IRAC), Córdoba, Argentina, pp.171-190.

Pessoa GA, Martini AP, Chaiben MFC, Vieira LM, Girotto RW, Pugliesi G, Santin T, Rubin MIB, Baruselli PS, Sá Filho M. 2015. Adjustment of the estradiol benzoate dose in the resynchronization protocol with unknown pregnancy status in suckled beef cows. Anim Reprod, 12:610. (Abstract).
Peterson C, Alkar A, Smith S, Kerr S, Hall JB, Moore D, Kasimanickam R. 2011. Effects of one versus two doses of prostaglandin F2alpha on AI pregnancy rates in a 5-day progesterone-based, $\mathrm{CO}$ Synch protocol in crossbred beef heifers. Theriogenology, 75:1536-1542.

Pincinato D. 2012. Follicular dynamics and fertility in beef suckled cows synchronized with progesterone releasing devices and GnRH. Master of Science Thesis. Faculty of Agriculture Sciences, National University of Cordoba, Cordoba, Argentina.

Pugliesi G, Miagawa BT, Paiva YN, Franc, a MR Silva LA, Binelli M. 2014. Conceptus-induced changes in the gene expression of blood immune cells and the ultrasound-accessed luteal function in beef cattle: how early can we detect pregnancy? Biol Reprod, 91:95, 1-12. Pugliesi G, Rezende RG, Silva JCB, Lopes E, Nishimura TK, Baruselli PS, Madureira EH, Binelli M. 2017. Uso da ultrassonografia Doppler em programas de IATF e TETF em bovinos. Rev Bras Reprod Anim, 41:140-150.

Rezende RG, Freitas BG, Mingoti RD, Colli MHA, Carvalho JBP, Sá Filho MF, Motta JCL, Macedo GG, Baruselli PS. 2016. Follicular dynamics of Nelore cows submitted to resynchronization 14 days after TAI using injectable P4 for synchronization of follicular wave. Anim Reprod, 13:375. (Abstract).

Richardson BN, Hill SL, Stevenson JS, Djira GD, Perry GA. 2016. Expression of estrus before fixed-time AI affects conception rates and factors that impact expression of estrus and the repeatability of expression of estrus in sequential breeding seasons. Anim Reprod Sci, 166:133-140.

Sá Filho MF, Ayres H, Ferreira RM, Marques MO, Reis EL, Silva RC, Rodrigues CA, Madureira EH, Bó GA, Baruselli PS. 2010. Equine chorionic gonadotropin and gonadotropin-releasing hormone enhance fertility in a norgestomet-based, timed artificial insemination protocol in suckled Nelore (Bos indicus) cows. Theriogenology, 73:651-658.

Sá Filho MF, Crespilho AM, Santos JE, Perry GA, Baruselli PS. 2010. Ovarian follicle diameter at timed insemination and estrous response influence likelihood of ovulation and pregnancy after estrous synchronization with progesterone or progestin-based protocols in suckled Bos indicus cows. Anim Reprod Sci, 120:23-30.

Sá Filho MF, Marques MO, Girotto R, Santos FA, Sala RV, Barbuio JP, Baruselli PS. 2014. Resynchronization with unknown pregnancy status using progestin-based timed artificial insemination protocol in beef cattle. Theriogenology, 81:284-290

Siqueira LG, Areas VS, Ghetti AM, Fonseca JF, Palhao MP, Fernandes CA, Viana JH. 2013. Color Doppler flow imaging for the early detection of nonpregnant cattle at 20 days after timed artificial insemination. J Dairy Sci, 96:6461-6472.

Small JA, Colazo MG, Kastelic JP, Mapletoft RJ. 2009. Effects of progesterone presynchronization and eCG on pregnancy rates to GnRH-based, timed-AI in beef cattle. Theriogenology, 71:698-706.

Souto LA, Maquivar M, Mussard ML, Bridges GA, 
Grum DE, Day ML. 2009. Fertility and luteal regression with 5-d CIDR synchronization programs in postpartum beef cows using differing luteolytic treatments J Anim Sci, 87 (Suppl 2):372. (Abstract).

Vieira LM, Sá Filho MF, Pugliesi G, Guerreiro BM, Cristaldo MA, Batista EOS, Freitas G, Carvalho FJ, Guimaraes LHC, Baruselli PS. 2014 Resynchronization in dairy cows 13 days after TAI followed by pregnancy diagnosis based on corpus luteum vascularization by color Doppler. Anim Reprod,
11:378. (Abstract).

Vishwanath R. 2015. Sexed sperm vs conventional sperm - a comparative discussion. Proceedings 7th Applied Reproductive Strategies in Beef Cattle Symposium, Davis, CA, pp.250-256.

Whittier WD, Currin JF, Schramm H, Holland S, Kasimanickam RK. 2013. Fertility in Angus cross beef cows following 5-day CO-Synch + CIDR or 7-day COSynch + CIDR estrus synchronization and timed artificial insemination. Theriogenology, 80:963-969. 